\title{
A humán parechovírusok klinikai jelentősége súlyos újszülött- és csecsemőkori fertőzésekben hazánkban
}

\author{
Boros Ákos dr. ${ }^{1,2^{*}}$ - Hamarics Zsófia dr. ${ }^{1,2^{*}}$ \\ Fenyvesi Hajnalka dr. ${ }^{1,2}$ - Liptai Zoltán dr. ${ }^{3}$ - Nyul Zoltán dr. ${ }^{4}$ \\ Pankovics Péter dr. ${ }^{1,2}$. Reuter Gábor dr. ${ }^{1,2}$ \\ 'Állami Népegészségügyi és Tisztiorvosi Szolgálat Dél-dunántúli Regionális Intézete, \\ Regionális Virológiai Laboratórium, Gastroenterális Vírusok Nemzeti Referencia Laboratóriuma, Pécs \\ ${ }^{2}$ Pécsi Tudományegyetem, Orvostudományi Kar, Klinikai Központ, \\ Orvosi Mikrobiológiai és Immunitástani Intézet, Pécs \\ ${ }^{3}$ Dél-pesti Centrum Kórház - Országos Hematológiai és Infektológiai Intézet, Szent László Kórház Telephely, \\ Gyermekinfektológiai Osztály, Budapest \\ ${ }^{4}$ Pécsi Tudományegyetem, Orvostudományi Kar, Klinikai Központ, Gyermekgyógyászati Klinika, Pécs
}

\begin{abstract}
Bevezetés: A humán parechovírus (HPeV, Picornaviridae víruscsalád) okozta fertőzések többsége tünetmentes, de gyermekeknél hasmenéssel járhatnak. Újabb megfigyelés, hogy a $\mathrm{HPeV}$-ok a csecsemők körében súlyos, központi idegrendszeri megbetegedést és szepszisszerü kórképet is okozhatnak. A HPeV-ok szerepe a hazai klinikumban nem ismert.

Célkitüzés: A HPeV-ok kimutatása, meghatározása gyermekektől származó székletmintákból és a klinikai tünetek elemzése.

Módszer: A HPeV-ok kimutatása és tipizálása a reverz transzkripció-polimeráz-láncreakció és a szekvenálás módszereivel történt három betegcsoportban: A) 10 év alatti kórházban kezelt, $\mathrm{n}=75$; B) $\mathrm{l}$ év alatti, $\mathrm{n}=237$; és C) szisztémás/idegrendszeri tüneteket is mutató hasmenéses gyermekek (<18 év), n = 105 székletmintáiból.

Eredmények: Az A csoportban 4\% (3/75) volt a HPeV-pozitív minták aránya (két HPeVl, egy nem tipizálható $\mathrm{HPeV})$, mind gastroenteralis tüneteket mutató csecsemőkből (7-11 hónapos). A B csoportban a HPeV-fertőzések aránya 6,8\% (16/237) volt, melyek közül öt HPeVl, hat HPeV3 és öt nem tipizálható HPeV volt. E csoportban a HPeVl-fertőzések többsége (4/5) nem igényelt kórházi ellátást, míg a HPeV3-fertőzéses esetek 83\%-a (5/6) igényelte azt. A szisztémás/idegrendszeri tüneteket is mutató betegekből (C csoport) azonosított HPeV-pozitív minták $(4,8 \%)$ két genotípusba tartoztak (három HPeVl és két HPeV3), és mind kórházban kezelt fiatal ( $\leq 2$ hónapos) csecsemóktől származtak.

Következtetés: A HPeVl-fertőzések általában enyhébb lefolyásúak, és ritkábban igényelnek kórházi ellátást. A HPeVlfertőzés vezető tünete a hasmenés, azonban 1-2 hónapos csecsemőknél idegrendszeri érintettség (aluszékonyság, bágyadtság) is tapasztalható volt. Az újszülöttek körében a HPeV3-megbetegedések gyakoribbak. A súlyos HPeV3fertőzésre jellemzőek a gastroenteralis tünetek (7/8), a $\geq 38^{\circ} \mathrm{C}$-os láz $(6 / 7)$, az étvágytalanság (6/7), az exanthema (4/7), az aluszékonyság/bágyadtság (3/7), a szepszisszerú állapot $(3 / 7)$ és a légzőszervi tünetek (2/7).

Orv Hetil. 2019; 160(10): 386-395.
\end{abstract}

Kulcsszavak: humán parechovírus, gastroenteritis, szepszis, újszülött, csecsemő

\section{The clinical significance of severe human parechovirus infections in newborns and infants in Hungary}

\begin{abstract}
Introduction: Most human parechovirus ( $\mathrm{HPeV}$, family Picornaviridae) infections are asymptomatic but may cause gastroenteritis in children. New reports show that HPeVs can be associated with severe central nervous system symptoms and sepsis-like syndromes in infants. The clinical significance of HPeVs in Hungary has not been investigated before.
\end{abstract}

*A szerzók azonos mértékben járultak hozzá a tanulmány elkészítéséhez. 
Aim: The aim of this study was to detect genotype $\mathrm{HPeV}$ in faecal samples of children and analysis of the clinical symptoms.

Method: For the detection and genotyping of $\mathrm{HPeV}$ strains, reverse transcription-polymerase chain reaction and sequencing methods were used from faecal samples of children with gastroenteritis divided into three groups: group A) hospitalised children younger than 10 years $(n=75)$; group $B) 0-12$ months infants $(n=237)$ and group C) children less than 18 years of age with sepsis-like/neurological symptoms $(n=105)$ were tested.

Results: Three $\mathrm{HPeV}$ positive samples $(3 / 75,4 \%)$ were found in group A, two of them belong to the HPeV type 1 , the third was non-typeable. All positive samples were from infants of 7 to 11 months of age. In group B, HPeV was detected in $6.8 \%(16 / 237)$ of the samples. Five were HPeVl, six were HPeV3 and five were non-typeable. While most of the infants with HPeVl $(4 / 5)$ did not require hospitalisation, $83 \%$ of the HPeV3 infected infants $(5 / 6)$ did. Five (4.8\%) HPeV strains detected from children less than 18 years of age with sepsis-like/neurological symptoms (group C) belonged to $\mathrm{HPeVl}$ (three) and $\mathrm{HPeV} 3$ (two). All positive samples were from hospitalised infants less than 2 months of age.

Conclusion: $\mathrm{HPeVl}$ infections are less severe in infants than HPeV3 infections. The leading symptom of $\mathrm{HPeVl}$ was diarrhoea, although in infants less than 1-2 months neurological symptoms (somnolence, lassitude) were also present. HPeV3 infections were more common among newborns. The main symptoms of severe $\mathrm{HPeV} 3$ infection are: gastroenteritis $(7 / 8)$, fever $\geq 38^{\circ} \mathrm{C}(6 / 7)$, loss of appetite (6/7), rash (4/7), somnolence/lassitude (3/7), sepsis-like syndrome $(3 / 7)$ and respiratory symptoms $(2 / 7)$.

Keywords: human parechovirus, gastroenteritis, sepsis, newborns, infants

Boros Á, Hamarics Zs, Fenyvesi H, Liptai Z, Nyul Z, Pankovics P, Reuter G. [The clinical significance of severe human parechovirus infections in newborns and infants in Hungary]. Orv Hetil. 2019; 160(10): 386-395.

(Beérkezett: 2018. szeptember 11.; elfogadva: 2018. szeptember 28.)

\section{Rövidítések}

ÁNTSZ = Állami Népegészségügyi és Tisztiorvosi Szolgálat; BLAST = Basic Local Alignment Search Tool; CRP = C-reaktív protein $; \mathrm{HPeV}=$ humán parechovírus; $\mathrm{IC}=$ (immunochromatography) immunkromatográfia; $\mathrm{MR}=$ (magnetic resonance) mágneses rezonancia; NCBI $=($ National Center for Biotechnology Information) az Egyesült Államok Nemzeti Biotechnológiai Információs Központja; $\mathrm{NoV}=$ norovírus; ORF = (open reading frame) nyílt leolvasási keret; RT-PCR = (reverse transcription-polymerase chain reaction) reverz transzkripciópolimeráz-láncreakció; $\mathrm{RV}=$ rotavírus $; \mathrm{UTR}=$ (untranslated region) nem kódoló régió; $\mathrm{VP}=$ virális protein

Albert Sabin és mtsa ismeretlen etiológiájú csecsemőkori hasmenéses székletmintákból azonosították az első humán parechovírusokat (HPeV) 1956-ban, melyeket akkor még mint ECHO-vírus (enteric cytopathic human orphan) 22 és 23 néven a Picornaviridae víruscsalád Enterovirus nemzetségébe soroltak [1]. 1999-ben - 43 évvel később -, miután e vírusok teljes genomszekvenciája ismertté vált, helyezték át őket az újonnan létrehozott Parechovirus nevú nemzetségbe [2]. A nemzetségbe jelenleg négy faj (Parechovirus A-D) tartozik [3], melyek közül a Parechovirus $A$-fajba tartoznak a humán parechovírusok, köztük az ECHO-vírus 22 (ma HPeVl) és 23 (ma HPeV2) is [3]. A HPeV3-at 1999-ben, Japánban, tranziens paralízissel, magas lázzal és hasmenéssel kórházba került l éves kislány mintájából azonosították [4]. Azóta a humán parechovírusok további 16, összesen 19 (HPeVl-19) különbözố típusát írták le [5]. Ezek kö- zül a különböző molekuláris epidemiológiai vizsgálatok szerint a leggyakrabban előforduló genotípus a HPeVl-es és a HPeV3-as, melyek lokális járványokat is okozhatnak [5-7]. A HPeVl- és HPeV4-genotípusok jelenlétét korábban már hazánkban is igazolták $[8,9]$.

A HPeV-ok pozitív polaritású, egyszálú RNS-genommal rendelkeznek, melynek hossza 7,1-7,3 kilobázis [2]. A genom egy virális poliproteint kódoló nyílt leolvasási keretből (ORF), az 5' és 3' végeken nem kódoló régióból (UTR), valamint a 3 ' végen poliadeninfarokból épül fel [2]. Az 5'UTR régió a HPeV különböző genotípusaiban erősen konzervatív, ezért a különböző RT-PCR-kban alkalmazott szűrôprimerek célszekvenciáiként alkalmazhatók, azonban az 5'UTR genotípusfüggetlen konzervációja miatt genotipizálásra nem használhatók $[8,10]$. A virális poliprotein strukturális Pl (kapszid fehérjéket kódoló) és nem strukturális P2 és P3 (nem strukturális fehérjéket kódoló) részekre osztható [11]. A HPeV virionja ikozaéder formájú kapszidját a VP0, VP3 és VPl kapszid fehérjék alkotják [12]. A kapszid fehérjéket kódoló régió variábilis, és az egyes $\mathrm{HPeV}$-genotípusok szekvenciaszintû elkülönítésére (genotipizálás) használhatók $[10,13]$.

A HPeV-ok világszerte elterjedt kórokozók. Elsősorban széklettel, fekális-orális úton, részben feltehetően a légutakon keresztül terjednek. A családban élő testvérek rizikófaktornak számíthatnak az expozíciónak kitett újszülöttek és csecsemő́k szempontjából [14]. A testvérek közötti átvitelt más tanulmányok is megerősítik [ 15 , 16]. A humán populációban endémiásan jelen vannak, és 
az átfertőződés mértéke igen magas. A felnőtt lakosság nagy része, 95\%-a szeropozitív HPeVl-re. A legtöbb esetben a fertőződés már 18 hónapos korig megtörténik, a fertőzések csak körülbelül 20\%-a történik az első életév betöltése után [13]. A HPeV-ok klinikai jelentőségét az irodalmi adatok alapján korábban már részletesen összefoglaltuk $[8,9]$. A HPeV-fertőzés klinikai megjelenése igen változatos lehet. A tünetek súlyossága az aszimptomatikus, szubklinikai formáktól egészen a súlyos, akár halálhoz vezető fertőzésekig terjedhet $[5,17]$. A gastrointestinalis tünetek (például hasmenés) gyakoriak, emellett gyakran tapasztalható láz is („lázas virális fertőzés”). A tünetek súlyossága nagyban függ az életkortól és feltehetóleg a HPeV genotípusától is $[2,5]$.

A HPeVl-fertőzés általában csecsemő- és kisgyermekkorban enyhébb lefolyású, fóleg gastroenteralis, illetve légúti tünetekkel jár, ritka a központi idegrendszert érintő kórkép. Ezzel ellentétben a HPeV3-fertőzés gyakrabban érint újszülötteket, és gyakoribb a hasmenés mellett a súlyos, változatos tünetekkel és akár szepszisszerü képpel jellemezhető lefolyás, valamint a központi idegrendszeri érintettség (meningitis, encephalitis, flaccid paralízis, görcsrohamok), ritkán akár maradandó idegrendszeri károsodással $[5,17,18]$. Bár a HPeVl- és HPeV4genotípusok hazai jelenléte archivált szövettenyészetekben már korábbról ismert $[8,9]$, mivel az egyes $\mathrm{HPeV}$-típusok csak típustól függően tenyészthetők [2], ezek az eredmények nem nyújtanak átfogó képet a hazai HPeV-típusokról. A klinikailag legsúlyosabb fertőzéseket okozó HPeV3 hazai jelenlétét tudomásunk szerint még nem igazolták.

Vizsgálataink során több, különböző korcsoportba tartozó, 18 év alatti gyermekektől származó székletmintákat elemezve arra kerestük a válaszokat, hogy: (i) milyen korcsoportú betegekben fordul elő HPeV-fertőzés hazánkban? (ii) Milyen $\mathrm{HPeV}$-típusok cirkulálnak Magyarországon? (iii) Milyen tünetekkel hozhatók összefüggésbe az azonosított $\mathrm{HPeV}$-típusok? (iv) A tünetek súlyossága, illetve a kórházi kezelés szükségessége alapján milyen korcsoportok a legveszélyeztetettebbek? (v) A veszélyeztetett korcsoportokba tartozó betegek milyen közös tünetei utalhatnak $\mathrm{HPeV}$-fertőzésre, amelyek elősegíthetik az időbeli és helyes klinikai diagnózis megállapítását? Vizsgálatainkhoz saját tervezésű $\mathrm{HPeV}$ szúrő és -tipizáló primereket, RT-PCR-módszert használtunk, valamint nukleotidszekvencia-elemzést és a klinikai háttéradatok elemzését végeztük el.

\section{Módszer}

\section{Vizsgált mintacsoportok}

A vizsgált székletmintákat három csoportba soroltuk.

A csoport: A 2011. évben a Dél-Dunántúlon (Baranya, Somogy és Tolna megye) gyüjtött összesen 75, kórházi ellátást igénylő, 10 év alatti gyermektől származó székletminták, melyek diagnosztikus vizsgálatra érkeztek a laboratóriumunkba.

B csoport: A 2015 júliusa és 2016 júniusa között összesen 237, ápolási helytől függetlenül (kórházi vagy otthoni ápolású egyaránt) gyújtött, 1 év alatti hasmenéses dél-dunántúli (Baranya, Somogy és Tolna megye) gyermekektől származó minta, melyek diagnosztikus vizsgálatra érkeztek a laboratóriumunkba.

C csoport: Enterovírus és/vagy humán parechovírus kimutatására a Baranya Megyei Kormányhivatal Népegészségügyi Főosztályának Mikrobiológiai Laboratóriumába (korábban az ÁNTSZ Dél-dunántúli Regionális Intézete) 2012 és 2018 között beküldött, összesen 105, szisztémás/idegrendszeri tüneteket is mutató, 18 év alatti betegektől származó székletminta. A minták a déldunántúli régióból, illetve a budapesti Szent László Kórház beteganyagából származtak.

A három csoportba tartozó gyermekek egyike esetében sem lehetett a betegellátás során a különböző diagnosztikus célokra vett mintákból (széklet és/vagy vér, liquor) rutin enteralis bakteriológiai és parazitológiai vizsgálatokkal kórokozót kimutatni. A három csoport székletmintáit a vizsgálatok kezdetéig $-20{ }^{\circ} \mathrm{C}$-on tároltuk.

1. táblázat | A humán parechovírusok $(\mathrm{HPeV})$ kimutatására (szűrés) és tipizálására (tipizálás), valamint a norovírus (NoV)-társfertőzés azonosítására használt oligonukleotid primerek listája. \#: A termék mérete a HPeV-5UTR-Fgen primerrel közös RT-PCR-ra vonatkozik

\begin{tabular}{|c|c|c|c|c|}
\hline A primer neve & Szekvencia $\left(5^{\prime}-3^{\prime}\right)$ & $\begin{array}{l}\text { Felhasználás } \\
\text { (RT-PCR) }\end{array}$ & A termék mérete & Referencia \\
\hline HPeV-5UTR-Rgen & CCAGATCAGATCCATAGTGTC & Szürés & & - \\
\hline HPeV-5UTR-Fgen & GATGGCGTGCCATAAYTCTA & Szürés & $351 \mathrm{bp}$ & - \\
\hline HPeV-VP0-Rgen & ACCTGAAWRTGRAADCCACA & Tipizálás & 960 bp\# & - \\
\hline HPeV-VP3-Rgen & TGAACCCCAIGAATTYTGGAA & Tipizálás & & - \\
\hline HPeV-VP3-Fgen & CCCCTATGTTKCWGACACAAACTA & Tipizálás & $968 \mathrm{bp}$ & - \\
\hline HPeV-VPl-Rgen & TCTCCIACWATRATRCCATART & Tipizálás & & - \\
\hline HPeV-VPl-Fgen & TTCITGGGGHTCMCARATGG & Tipizálás & $780 \mathrm{bp}$ & - \\
\hline NoV-JV13I-R & TCATCATCACCATAGAAIGAG & Tipizálás & & {$[20]$} \\
\hline NoV-JV12Y-F & ATACCACTATGATGCAGAYTA & Tipizálás & 289 bp & {$[20]$} \\
\hline
\end{tabular}

$\mathrm{RT}-\mathrm{PCR}$ = reverz transzkripció-polimeráz-láncreakció; VP = virális protein 


\section{Molekuláris diagnosztika, HPeV-tipizálás és filogenetikai analizis}

A HPeV-ok kimutatása RT-PCR-módszerrel történt. A kimutatási reakciókhoz egy új, a vírusnak a genotípustól függetlenül konzervatív 5'UTR régiójához kötődő szúró primerpárt (HPeV-5UTR-R/F, 1. táblázat) terveztünk, amely alkalmas lehet az eddig azonosított összes $\mathrm{HPeV}$-genotípus kimutatására, azonban genotipizálásra nem. A szűrő́ primerpárral azonosított $\mathrm{HPeV}$-törzsek tipizáló RT-PCR-iban a kapszidrégió különböző részeire (VP0, VP3 és VP1) tervezett erősen degenerált tipizáló primerpárokat használtunk (1. táblázat). A kapott PCRtermékeket mindkét irányból direkt módon szekvenáltuk, melyhez BigDye Terminator Cycle Sequencing Ready Reaction kit-et (Applied Biosystems, Warrington, Egyesült Királyság) és automata szekvenátort használtunk
(ABI PRISM 310 Genetic Analyzer; Applied Biosystems, Foster City, CA, Egyesült Államok). A kapott szekvenciaadatok közül a filogenetikai vizsgálatokhoz használt 17 VP3- és 6 VPl-szekvenciát a GenBank-adatbázisba helyeztük el (VP3-szekvenciák: MH845197-MH845213, VPl-szekvenciák: MH845214-MH845219).

A HPeV-tipizálási RT-PCR-k PCR-termékeinek szekvenálásával kapott szekvenciákat GeneDoc ver. 2.7. programmal, illetve az NCBI (National Center for Biotechnology Information) BLAST-programcsaládjával (https://blast.ncbi.nlm.nih.gov/Blast.cgi) elemeztük. A kimutatott $\mathrm{HPeV}$-törzsek tipizálásakor a BLAST-futtatások találati listájából a legmagasabb szekvenciaegyezést és a legalacsonyabb E-értéket mutató $\mathrm{HPeV}$-genotípust vettük figyelembe. A HPeV VP3- és VPl-régióinak filogenetikai elemzéséhez a referenciaszekvenciákat a GenBank (http://www.ncbi.nlm.nih.gov) adatbázisából

2. táblázat |A különböző humán parechovírusok (HPeV) szúrő (5'UTR oszlop) és tipizáló (VP3, VPl és VP0 oszlopok) RT-PCR-k eredményei, a kimutatott $\mathrm{HPeV}$ genotípusai (Típus oszlop), valamint a társfertőzéses vizsgálatok eredményei (Rotavírus, Adenovírus és Norovírus oszlopok). n.v.: nem végzett vizsgálat (VP0 RT-PCR-t csak akkor végeztünk, ha az adott mintából nem kaptunk pozitív RT-PCR-eredményt a VP3 és/vagy VPl HPeV-tipizáló primerekkel). A mintaazonosító első betúje a mintacsoportra utal. A mintavétel ideje és az ország rövidítése (év/hónap/HUN) a mintaazonosító végén található

\begin{tabular}{|c|c|c|c|c|c|c|c|c|c|}
\hline Mintacsoport & Mintaazonosító & 5'UTR & VP3 & VP1 & VP0 & Típus & Rotavírus & Adenovírus & Norovírus \\
\hline \multirow[t]{3}{*}{ A csoport } & A-524-2011/01/HUN & + & + & - & n.v. & $\mathrm{HPeVl}$ & - & - & - \\
\hline & A-478-2011/01/HUN & + & - & - & - & HPeV? & - & - & + \\
\hline & A-77141-2011/09/HUN & + & + & + & n.v. & HPeVl & - & - & - \\
\hline \multirow[t]{16}{*}{ B csoport } & B-1885-2015/07/HUN & + & - & - & - & HPeV? & - & - & - \\
\hline & B-7326-2015/08/HUN & + & + & - & n.v. & $\mathrm{HPeV} 3$ & - & - & - \\
\hline & B-1746-2015/08/HUN & + & + & - & n.v. & $\mathrm{HPeV} 3$ & - & - & - \\
\hline & B-6167-2015/09/HUN & + & - & - & - & HPeV? & + & - & - \\
\hline & B-4838-2015/10/HUN & + & - & - & - & HPeV? & - & - & - \\
\hline & B-4048-2015/10/HUN & + & + & + & n.v. & $\mathrm{HPeV} 3$ & - & - & - \\
\hline & B-3539-2015/11/HUN & + & + & - & n.v. & HPeVl & - & - & - \\
\hline & B-0569-2015/12/HUN & + & + & + & n.v. & $\mathrm{HPeVl}$ & - & - & - \\
\hline & B-2789-2015/12/HUN & + & + & + & n.v. & $\mathrm{HPeVl}$ & - & - & - \\
\hline & B-21301-2015/12/HUN & + & - & - & - & HPeV? & - & - & - \\
\hline & B-414-2016/01/HUN & + & + & - & n.v. & HPeVl & - & - & - \\
\hline & B-176-2016/01/HUN & + & + & - & n.v. & $\mathrm{HPeV} 3$ & - & - & - \\
\hline & B-578-2016/02/HUN & + & - & - & - & HPeV? & - & - & + \\
\hline & B-9792-2016/02/HUN & + & + & + & n.v. & HPeVl & - & - & - \\
\hline & B-4264-2016/06/HUN & + & + & - & n.v. & $\mathrm{HPeV} 3$ & - & - & - \\
\hline & B-3194-2016/06/HUN & + & + & - & n.v. & HPeV3 & - & - & - \\
\hline \multirow[t]{5}{*}{ C csoport } & C-2422-2014/04/HUN & + & + & + & n.v. & HPeVl & + & - & - \\
\hline & C-21611-2012/07/HUN & + & - & - & + & $\mathrm{HPeVl}$ & - & - & - \\
\hline & C-02502-2016/08/HUN & + & + & - & n.v. & $\mathrm{HPeV} 3$ & - & - & - \\
\hline & C-6168-2016/01/HUN & + & + & - & n.v. & HPeV3 & - & - & - \\
\hline & C-383-2018/01/HUN & + & + & - & n.v. & $\mathrm{HPeVl}$ & - & - & - \\
\hline
\end{tabular}

$\mathrm{RT}-\mathrm{PCR}$ = reverz transzkripció-polimeráz-láncreakció; VP = virális protein 


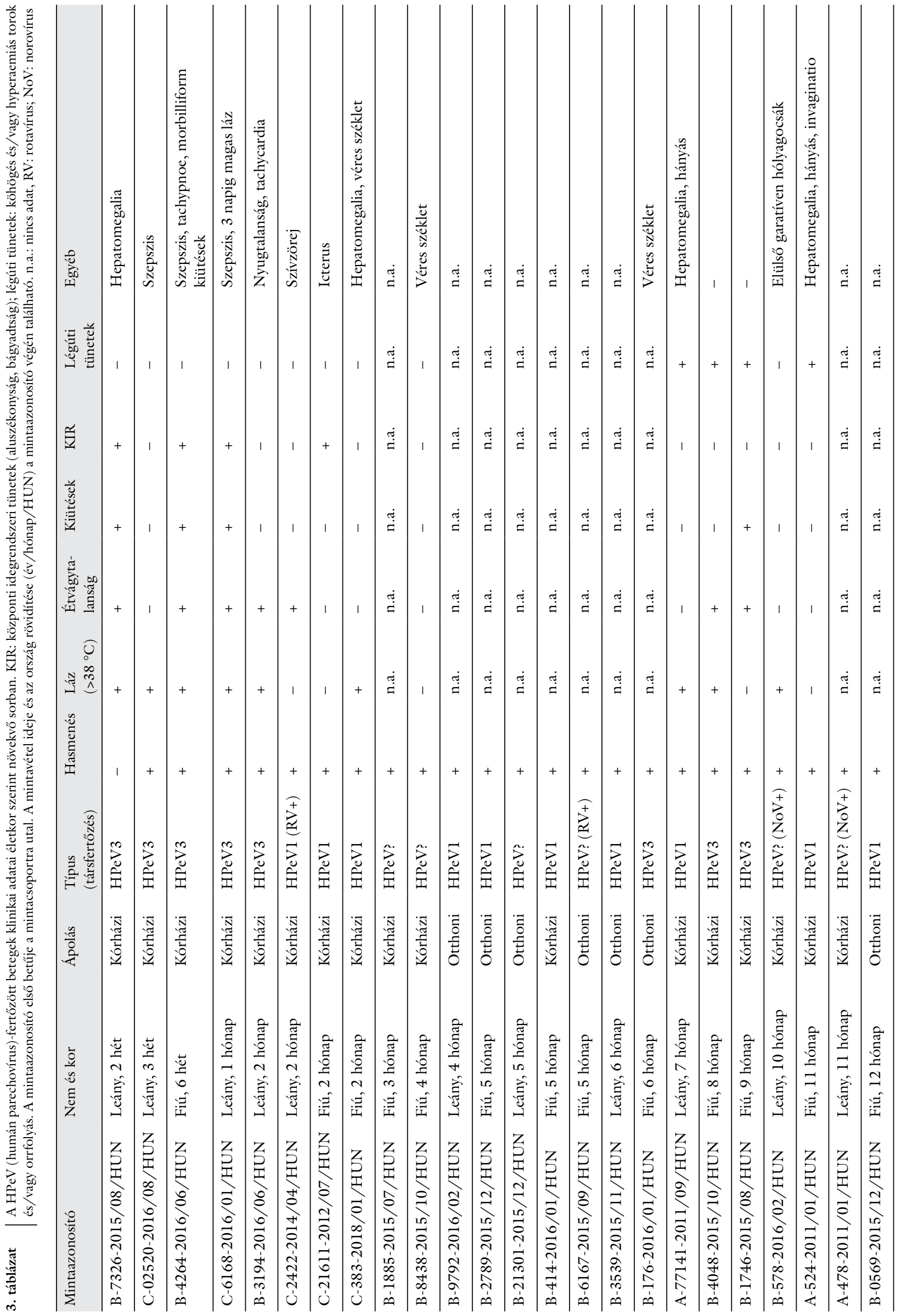


töltöttük le. A filogenetikai fák elkészítéséhez a MEGA v7.0 programot használtuk [19]. A HPeV-pozitív mintákon a rotavírus és az enteralis adenovírus kimutatását immunkromatográfiás (IC) gyorsteszttel (CerTest, BioTech, Spanyolország), míg a norovírus-társfertőzés kimutatását általános szűrőprimerekkel (1. táblázat) [20] és RT-PCR-módszerrel vizsgáltuk.

\section{Eredmények}

\section{A csoport}

A 2011-ben gyưjtött összesen 75, kórházi ellátást igénylő dél-dunántúli, 10 év alatti gyermek mintájából $\mathrm{N}=3$ volt $\mathrm{HPeV}$-pozitív az alkalmazott 5'UTR-szűrő RTPCR-módszerrel, mely 4\%-os $\mathrm{HPeV}$-kimutatási arányt jelent. A tipizálási RT-PCR-kban kapott részleges VP3és/vagy VPl-kapszidszekvenciák BLAST-analízise alapján kettő az egyes típusú HPeV-ok közé tartozott ( HPeVl, $\mathrm{N}=2$ ), a harmadik törzs pedig egyik tipizáló primerpárral sem adott PCR-terméket, ezért nem volt tipizálható ( $\mathrm{HPeV}$ ?, $\mathrm{N}=1$ ). Norovírus-társfertőzést egy esetben, a nem tipizálható HPeV-fertőzött betegnél találtunk (2. táblázat). Mindhárom $\mathrm{HPeV}$-pozitív minta 7-11 hónap közötti életkorú csecsemőktől származott (3. táblázat), ezért ennek alapján további vizsgálatainkat az egy év alatti újszülöttek és csecsemők csoportjára szükítettük le.

\section{$B$ csoport}

Ápolási helytől függetlenül (kórházi vagy otthoni ápolású egyaránt), l év alatti hasmenéses dél-dunántúli gyermekektől származó összesen 237 minta közül $16 \mathrm{HPeV}$ pozitív mintát találtunk, ami 6,8\%-os $\mathrm{HPeV}$-elófordulást jelent. A pozitív minták közül hat a hármas genotípus- hoz (HPeV3, N = 6), öt az egyeshez tartozott (HPeVl, $\mathrm{N}=5$ ), öt törzset pedig nem tudtunk a rendelkezésünkre álló primerekkel tipizálni. Kórházi kezelésre a $\mathrm{HPeV3-}$ mal fertőzött csecsemőknél hatból öt esetben (!), míg az egyes genotípussal fertőzött öt esetből csupán egyben volt szükség. Társfertőzést két esetben találtunk, mindkétszer nem tipizálható HPeV-fertőzés mellé társult norovírus- vagy rotavírusfertőzés (2. táblázat).

\section{C csoport}

Az idegrendszeri és/vagy szisztémás tüneteket mutató 18 év alatti betegektől származó 105 minta közül $\mathrm{N}=5$ $(4,8 \%)$ bizonyult HPeV-pozitívnak. A HPeV-törzsek közül kettő a hármas genotípushoz $(\mathrm{HPeV} 3, \mathrm{~N}=2)$, három pedig az egyes típushoz tartozott $(\mathrm{HPeVl}, \mathrm{N}=3)$, tipizálatlan törzs ebben a mintacsoportban nem volt (2. táblázat). Mind az öt pozitív minta 2 hónapos vagy fiatalabb csecsemőktől származott (3. táblázat). A HPeVl-es genotípussal fertőzötteknél 2 hónapos, a HPeV3-as genotípus esetében 1 hónapos kor alatti csecsemók voltak érintettek (3. táblázat). Rotavírus-társfertőzést egy intenzív osztályos ellátást igénylö HPeVl-fertőzött csecsemőnél találtunk (2. táblázat).

\section{Nem-, koreloszlás és szezonalitás}

A HPeV-sal fertőzött betegek korcsoporteloszlásának elemzése azt mutatta, hogy az összes pozitív minta 1 év alatti gyermekektől származott (1. ábra, 3. táblázat). Az 1 hónapos kor alatti csecsemók körében csak HPeV3 volt kimutatható $(\mathrm{N}=4)$, amelyeknél minden esetben intenzív osztályos kezelés volt szükséges (1. ábra, 3. táblázat). A HPeV-pozitivitás nemek közötti eloszlása nem mutatott szignifikáns különbséget: $\mathrm{HPeVl}$ : fiú $\mathrm{N}=6$, leány $\mathrm{N}=4$; $\mathrm{HPeV} 3$ : fiú $\mathrm{N}=4$, leány $\mathrm{N}=4$; összes

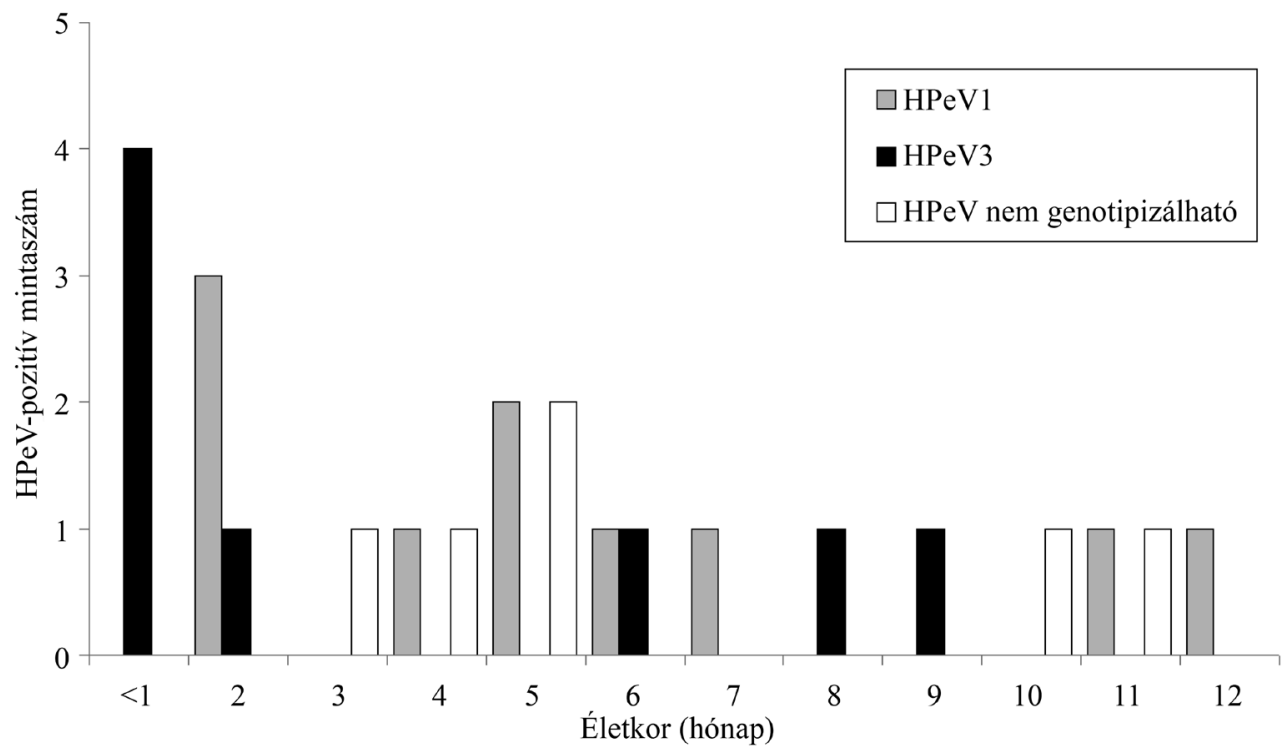

1. ábra | A három vizsgálati csoportból (A, B és C) azonosított HPeV-genotípusok korcsoportonkénti eloszlása 


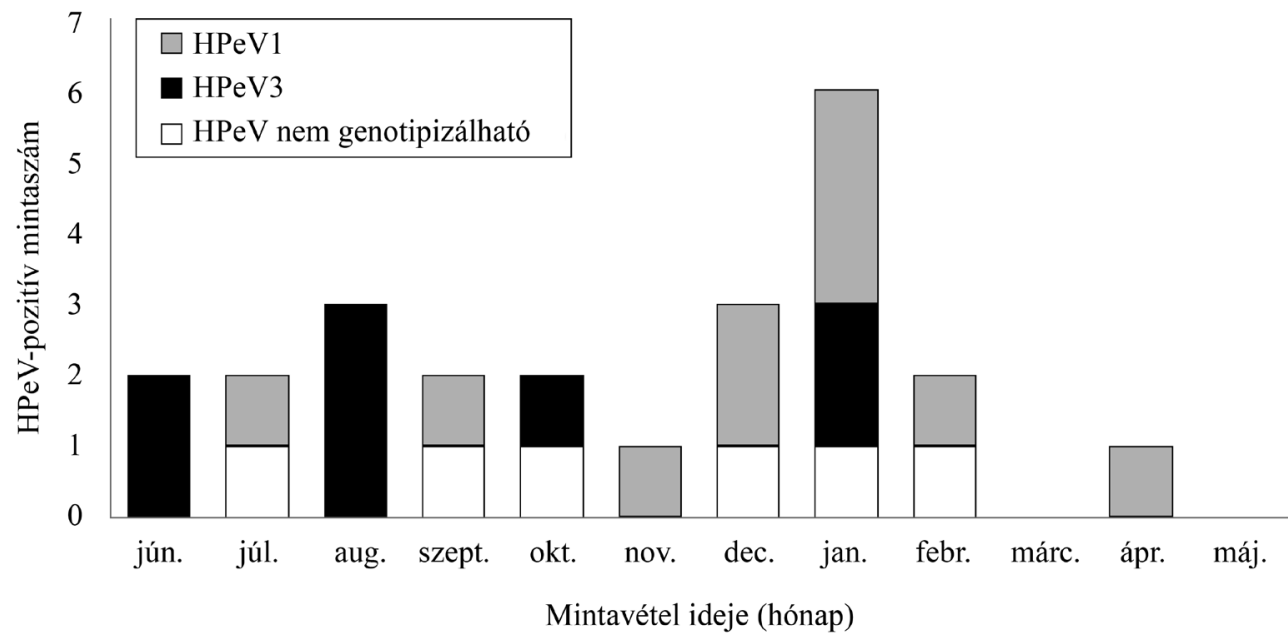

2. ábra

| A HPeV-ok szezonalitása a mintavétel ideje szerint (hónap)

$\mathrm{HPeV}$ : fiú $\mathrm{N}=13$, leány $\mathrm{N}=11$ (3. táblázat). Míg a $\mathrm{HPeV} 3$ esetében a vizsgált mintacsoportokban nem lehetett szezonalitást megfigyelni, addig a HPeVl-esetek enyhe halmozódását tapasztaltuk a téli hónapokban (2. ábra). Érdekességként jegyzendő meg, hogy összesen egy $\mathrm{HPeV}$-pozitív esetet azonosítottunk a tavaszi időszakból származó mintákból (2. ábra).

\section{A HPeV-pozitín betegek föbb tünetei}

Az összesen nyolc ( $\mathrm{B}$ csoport $\mathrm{N}=6 ; \mathrm{C}$ csoport $\mathrm{N}=2$ ) $\mathrm{HPeV} 3$-fertőzésre a legjellemzőbb tünet a hasmenés volt (7/8 esetben). Megjegyzés: Az egyik otthoni ápolású HPeV3-pozitív beteg (B-176-2016/01/HUN, 3. táblázat) klinikai tünetei közül a hasmenésen kívül nem állt rendelkezésünkre további adat, ezért a hasmenésen kívüli tünetek elemzésekor ezt a beteget nem vettük figyelembe. A gastroenteralis tünetek mellett a HPeV3fertőzéses esetekre jellemző volt a láz $\left(>38^{\circ} \mathrm{C}, 6 / 7\right.$ esetben), az étvágytalanság (6/7 esetben), az exanthema (4/7 esetben), a központi idegrendszeri érintettség (például aluszékonyság, bágyadtság, 3/7 esetben), a szepszisszerú állapot $(3 / 7)$ és ritkábban a légzőszervi (köhögés/orrfolyás és/vagy hyperaemiás torok, 2/7 esetben) tünetek (3. táblázat). A 2 hónapos csecsemők között előforduló HPeVl-fertőzés esetén a hasmenés mellett súlyosabb tünetek is megjelentek, mint például a sárgaság vagy az aluszékonyság (3. táblázat). Megjegyzendő az is, hogy a máj rendellenességére utaló jelek (hepatomegalia és icterus) többször megfigyelhetők voltak mind a HPeVl- (3 esetben), mind a HPeV3- (2 esetben) fertőzött csecsemők körében (3. táblázat).

\section{A hazai humán parechovirusok szekvencia- és filogenetikai elemzése}

A BLASTn-analízis eredményei alapján a tipizálási RTPCR-kban kapott, összesen 17 részleges VP3-szekvencia közül 9 a GenBank-ban található HPeVl- (91-98\%-os nukleotid- [nt] egyezés), míg 8 a HPeV3-törzsekkel (98-99\%-os nt-egyezés) mutatta a legmagasabb szekvenciaegyezést. Az összesen meghatározott 6 részleges VPl-szekvencia közül 5 a GenBank-ban található HPeVl- (96-98\%-os nt-egyezés), míg l a HPeV3-törzsekkel (98\%-os nt-egyezés) mutatta a legmagasabb szekvenciaegyezést.

A VP3- és VPl-nukleotidszekvenciák filogenetikai elemzése alátámasztotta a BLAST-analízisen alapuló $\mathrm{HPeV}$-tipizálást (3. ábra). A hazai HPeVl- és HPeV3törzsek több különböző filogenetikai ágon helyezkednek el, ami azt mutatja, hogy egy adott időszakban különféle leszármazási vonalhoz tartozó HPeVl- és HPeV3-törzsek is cirkuláltak egyidejúleg Magyarországon (3. ábra). Kiemelendő a 2015 novembere és 2016 februárja között gyưjtött mintákból kimutatott HPeVl-törzsek közeli genetikai rokonsága, ami esethalmozódásra/járványra utalhat (3. ábra).

\section{Megbeszélés}

Összesen 417, ismeretlen etiológiájú megbetegedésben szenvedő, három mintacsoportba tartozó (10 év alatti, kórházban kezelt; 1 év alatti, ápolási helytől független; és 18 év alatti, idegrendszeri/szisztémás tüneteket mutató) hazai betegből származó székletmintát vizsgáltunk humán parechovírus kimutatása és tipizálása céljából.

A vizsgált minták között összesen $24 \mathrm{HPeV}$-pozitív mintát azonosítottunk. A $\mathrm{HPeV}$-pozitív minták aránya 4\% (A csoport) és 6,8\% (B csoport) között változott, ami összhangban áll az irodalomban található előfordulási arányokkal a hasonló betegcsoportokban [4, 21, 22]. A $24 \mathrm{HPeV}$-törzsből 18 (75\%) esetében sikerült általános VP0-, VPl- és/vagy VP3-primerpárokkal a genotípust meghatározni. Szekvencia-összehasonlítási és filogenetikai elemzésekkel összesen két HPeV-genotípust ( $\mathrm{HPeVl}$ és $\mathrm{HPeV} 3$ ) tudtunk azonosítani, melyek irodalmi adatok 

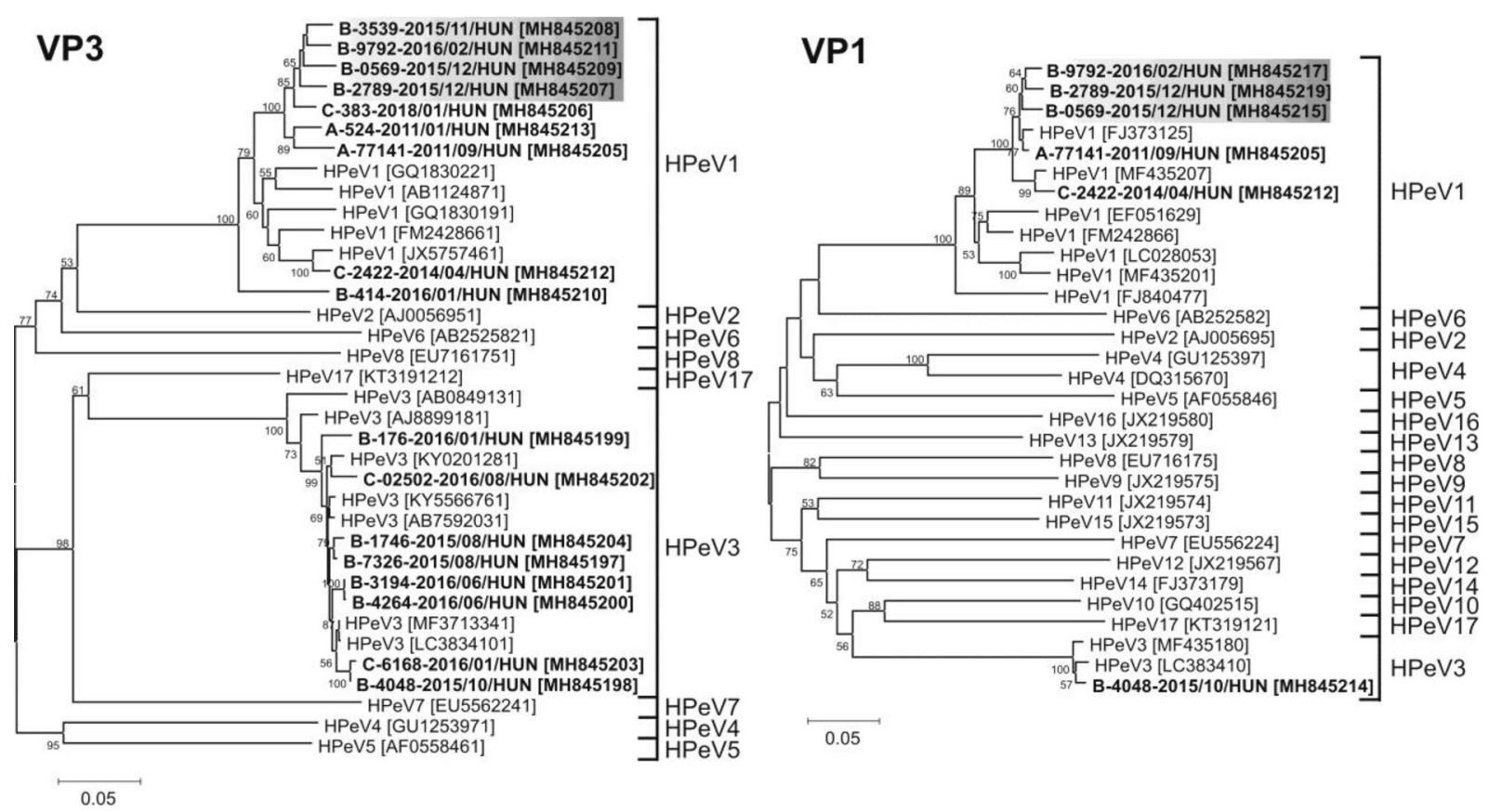

3. ábra

\begin{abstract}
A hazai HPeV-törzsek filogenetikai elemzése. Vizsgálataink során azonosított részleges VP3- (894 nt) és VPl- (687nt) nukleotidszekvenciákból (vastag betúk) és a HPeV-referenciaszekvenciákból készült filogenetikai fák 'neighbor joining' módszerrel és Jukes-Cantor-modell felhasználásával (bootstrap ismétlések száma: 1000) készültek MEGA 7.0 programmal. A mintaazonosító első betűje a mintacsoportra utal. A mintavétel ideje és az ország rövidítése (év/hónap/HUN) a mintaazonosító végén található. A GenBank-azonosítószámok szögletes zárójelben vannak. A szürke kiemelés a 2015 novembere és 2016 februárja között gyüjtött mintákból azonosított, filogenetikailag közeli rokonságot mutató HPeVl-törzseket jelzi

$\mathrm{HPeV}=$ humán parechovírus; $\mathrm{VP}=$ virális protein
\end{abstract}

alapján is a leggyakrabban kimutatható genotípusok a humán populációkban $[2,5,7]$. A HPeV3-at először sikerült hazánkban leírni. Bár az eddig ismert $19 \mathrm{HPeV}$ genotípusból hazánkban már a HPeVl mellett a HPeV4et is kimutatta munkacsoportunk $[8,9]$, a jelen tanulmányban az egyéb $\mathrm{HPeV}$-típusok hiánya talán az alacsony mintaszámnak köszönhető. Bár az általunk alkalmazott 5'UTR-szürő és VP1 - és VP3-tipizáló primerpárok elméletileg képesek az összes, ismert genommal rendelkező $\mathrm{HPeV}$-genotípus, köztük a HPeV4 kimutatására is, irodalmi adatok alapján tudjuk, hogy más genotípusokat is ritkábban azonosítanak [5, 7]. A tipizálatlan $\mathrm{HPeV}$-törzsek között elméletileg új típus(ok) is előfordulhatnak, bár a tipizálási reakciók sikertelenségének hátterében a vírus alacsony kópiaszáma a mintában vagy a tipizáló primerpárok tapadási helyének eltérő nukleotidszekvenciái is állhatnak.

A kimutatott $\mathrm{HPeV}$-ok VP3-as és VPl-es kapszidnukleotidszekvenciákon alapuló filogenetikai vizsgálatai, részben az adott genotípuson belül, különböző filogenetikai ághoz/altípushoz tartozó HPeVl- és HPeV3-vírustörzsek kocirkulációjára utalnak hazánkban. Ugyanakkor a filogenetikailag igen közeli rokonságot mutató HPeVl-törzsek - retrospektívan - egy esetleges, 2015 novembere és 2016 februárja között lezajlott dél-dunántúli HPeVl-es esethalmozódásra/járványra is utalhatnak. A HPeVl járványokozó képességére vannak nemzetközi irodalmi adatok [5-7], eddigi ismereteink szerint azonban a feltárt HPeVl-es esethalmozódás az első magyarországi dokumentált HPeVl-járvány lehet.

$\mathrm{Az}$ egyes $\mathrm{HPeV}$-típusok szezonalitásáról csak ellentmondó irodalmi adatok állnak rendelkezésre. A HPeVI esetében vagy nem volt kimutatható évszak-preferencia, vagy tavaszi/nyári (például Anglia), nyári/őszi szezonalitást (például Egyesült Államok), vagy éppen a tavaszi/ nyári időszak alacsony HPeVl-előfordulását (például Hollandia) találták [5-7, 18, 21]. A hollandiai HPeVelőforduláshoz hasonlóan [7] a mi vizsgálatainkban is csak a HPeVl esetén találtunk enyhe pozitívmintaszámemelkedést a téli időszakban.

A HPeV-fertőzés és a gastrointestinalis tünetek megjelenése közötti ok-okozati kapcsolat nem mindig bizonyítható egyértelműen [2], és ez fokozottan igaz, ha a $\mathrm{HPeV}$-on kívül más ismert, heveny gastroenteritist okozó vírus is jelen van a mintában. A HPeV jelenléte azonban a gyermekkori hasmenéses esetekben más gastroenteralis kórokozó mikroba hiánya esetén kórjelző lehet. Különösen fontos ez a megállapítás a HPeV3-fertőzésekre a csecsemőkori idegrendszeri és/vagy szisztémás megbetegedésekben, amelyeknél viszont a HPeV3 kimutatása ezekben a kórképekben diagnosztikus értékű lehet $[10,23]$. Virális társfertőzést összesen négy esetben mutattunk ki. Két esetben $\mathrm{HPeV} /$ norovírus és további két esetben $\mathrm{HPeV} /$ rotavírus társfertőzést azonosítottunk. Kórházi kezelésre a társfertőzések háromnegyedében volt szükség, ami a társfertőzések súlyosabb lefolyására utalhat. 
Vizsgálataink során a HPeV-fertőzések genotípustól függetlenül kizárólag az 1 év alatti gyermekeket érintették. Ez hasonló más irodalmi adatokhoz, amelyeknél a sporadikus esetektől és a HPeV3-járványtól eltekintve a klinikai tünetekkel járó HPeV-fertőzések többsége $(\sim 73 \%-a)$ az 1 év alatti csecsemókorban jelentkezett [2, $8,9,24]$. Míg a hazai HPeVl-fertőzött csecsemők átlagéletkora 5,6 hónap (2-12 hónap), addig a HPeV3-pozitívak átlagéletkora kevesebb, 4,1 hónap (<1-9 hónap) volt, ami összhangban van a HPeVl és HPeV3 eltérő életkori előfordulásával $[2,5]$.

A vizsgált mintacsoportokban a HPeV3 a leggyakrabban az újszülöttkorban (1 hónapos kor alatt) okozott megbetegedéseket. Ezzel szemben a HPeVl-fertőzések inkább 4 hónapos kor felett mutattak halmozódást. Az azonosított újszülöttkori HPeV3-fertőzések mindegyike kórházi, ezen belül is intenzív osztályos kezelést tett szükségessé. Hasonlóan súlyosabb kórképek jelentkeztek azokban az esetekben, amikor a HPeVl igen fiatal korban ( $\leq 2$ hónap) okozott fertőzést.

A későbbi életkorban ( $\geq 4$ hónap) okozott fertőzések a HPeVl esetében ritkábban (3/7 esetben, 43\%), a HPeV3 esetében azonban gyakrabban (2/3 esetben, 67\%) igényeltek kórházi kezelést. Ezek az eredmények arra utalnak, hogy a HPeV-fertőzések, kiváltképp a HPeV3-fertőzések gyakoribbak és súlyosabb lefolyásúak (akár intenzív osztályos ellátást igénylő) újszülött- és korai csecsemőkorban ( $\leq 2$ hónap), így ezt a korcsoportot tekinthetjük a legveszélyeztetettebbnek, amelyben a $\mathrm{HPeV} 3$ esetleges jelenléte a vírus kóroki szerepére és az eset súlyosságára is utalhat. Egy 2015-ben megjelent japán tanulmány azt mutatja, hogy összefüggés van az anyai $\mathrm{HPeV}$-átvészeltség (anyai $\mathrm{HPeV}$-ellenanyagok jelenléte vagy hiánya) és az újszülöttek/csecsemők $\mathrm{HPeV}$ tünetekkel járó megbetegedései között. Az anyai HPeV3-ellenanyagok jelenléte csökkenti a súlyos kimenetelű újszülöttkori HPeV3-fertőzés veszélyét, éppen ezért felmerül az intravénás immunglobulin (IVIG)-kezelés a súlyos HPeV-fertőzések esetében $[25,26]$.

A rendelkezésünkre álló adatok alapján a változó súlyosságú gastroenteralis tünetek voltak a leggyakoribbak, amelyek típustól függetlenül szinte bármely $\mathrm{HPeV}$-fertőzésnél jelen voltak. Ezt az eredményt azonban feltehetően a mintaszelekció is befolyásolta. A HPeV-fertőzött csecsemőknél hányás nélküli enyhe hasmenést (HPeVl), illetve akár napi többszöri $(\sim 15 \times)$ hasmenéssel és hányással $(3 \times)$ járó eseteket $(\mathrm{HPeV} 3)$ is találtunk. A betegek epidemiológiai adataiból az is kiderült, hogy mind az újszülöttkorban és korai csecsemókorban ( $\leq 2$ hónap), mind pedig a későbbi csecsemőkorban (8-9 hónap) a $\mathrm{HPeV} 3$-fertőzésekre jellemző a gastroenteralis tünetek mellett megjelenő, lázzal, étvágytalansággal, kiütésekkel vagy akár központi idegrendszeri, illetve légzőszervi tünetekkel járó változatos klinikai kép. Ha azonban a $\mathrm{HPeVl}$ a korai életkorban okoz fertőzést, akkor a kórházi ellátást igénylő hasmenés mellett súlyosabb tünetek is jelentkeztek, mint a sárgaság vagy az aluszékonyság. Fel- tehetően az ismeretlen eredetű gyermekkori, lázas virális fertőzések körében - gastroenteralis tünetek nélkül - a HPeV-fertőzéseknek további szerepük lehet. Vizsgálatunkban az eszközös (például MR, echokardiográfia stb.), kémiai laboratóriumi (például süllyedés, CRP, vérkép stb.), illetve az egyéb kiegészítő vizsgálatok eredményeire és jellegzetességeire nem térhettünk ki, mert ezek az adatok nem álltak a rendelkezésünkre az adatvédelmi szabályok miatt. Vizsgálataink hazánkban elsőként írják le és finomítják a HPeV-fertőzések klinikumát, de a HPeV-ok okozta klinikai kórképek spektruma minden bizonnyal még nem teljesen feltárt. Érdemes lenne a súlyos HPeV-fertőzött újszülöttek nyomon követése is az esetleges későbbi maradványtünetek feltárása érdekében.

Bár a HPeV-ok már több mint 60 éve ismertek, csak a közelmúlt molekuláris virológiai tanulmányai tárják fel e vírusok sokszínúségét és szerepét az egyes emberi fertőző megbetegedésekben $[2,5,6,13,18]$. Természetesen még számos megválaszolatlan kérdés felmerül a $\mathrm{HPeV}$-okkal kapcsolatban, de már a meglévő ismeretek is elégségesek arra, hogy a klinikusok (elsősorban az újszülött-, csecsemő- és gyermekorvosok) figyelmét felhívjuk a HPeV-ok okozta kórképekre, a fertőzés jellegzetességeire és a differenciáldiagnosztika fontosságára, mely a kezelést (például antibiotikum adása vagy elhagyása szepszisszerű kórképben) is befolyásolja. Csecsemő-, de különösen újszülöttkorban, amennyiben a gastrointestinalis tünetek mellett láz, étvágytalanság, aluszékonyság, exanthema, légzőszervi tünetek, valamit megmagyarázhatatlan szepszisszerú állapot, esetleg súlyos központi idegrendszeri elváltozások is jelentkeznek, a klinikai gyakorlatban (különösen, ha más ismert kórokozó jelenléte kizárható) gondoljunk a humán parechovírusfertőzés lehetőségére is.

Anyagi támogatás: A munka az Országos Tudományos Kutatási Alapprogramok OTKA/NKFIH K111615. számú pályázatának anyagi támogatásával készült. B. Á. és P. P. az MTA Bolyai János Kutatói Ösztöndíj támogatásában részesül.

Szerzői munkamegosztás: B. Á., R. G.: A vizsgálat megtervezése és irányítása. B. Á., H. Zs., R. G.: A közlemény megírása. H. Zs., B. Á., P. P., F. H.: A laboratóriumi vizsgálatok kivitelezése. B. Á., H. Zs., F. H.: A vizsgálati eredmények elemzése. L. Z., Ny. Z.: Mintaküldés és a klinikai háttéradatok összegyújtése. A cikk végleges változatát valamennyi szerző elolvasta és jóváhagyta.

Érdekeltségek: A szerzőknek nincsenek érdekeltségeik.

\section{Irodalom}

[1] Wigand R, Sabin AB. Properties of ECHO types 22, 23 and 24 viruses. Arch Gesamte Virusforsch. 1961; 11: 224-247.

[2] Harvala H, Simmonds P. Human parechoviruses: biology, epidemiology and clinical significance. J Clin Virol. 2009; 45: 1-9. 
[3] Zell R, Delwart E, Gorbalenya AE, et al. ICTV virus taxonomy profile: Picornaviridae. J Gen Virol. 2017; 98: 2421-2422.

[4] Ito $M$, Yamashita $T$, Tsuzuki $H$, et al. Isolation and identification of a novel human parechovirus. J Gen Virol. 2004; 85: 391-398.

[5] Olijve L, Jennings L, Walls T. Human parechovirus: an increasingly recognized cause of sepsis-like illness in young infants. Clin Microbiol Rev. 2018; 31: e00047-17.

[6] van der Sanden S, de Bruin E, Vennema H, et al. Prevalence of human parechovirus in the Netherlands in 2000 to 2007. J Clin Microbiol. 2008; 46: 2884-2889.

[7] Benschop K, Thomas X, Serpenti C, et al. High prevalence of human Parechovirus $(\mathrm{HPeV})$ genotypes in the Amsterdam region and identification of specific $\mathrm{HPeV}$ variants by direct genotyping of stool samples. J Clin Microbiol. 2008; 46: 3965-3970.

[8] Boros Á, Új M, Pankovics P, et al. Detection and characterization of human parechoviruses in archived cell cultures, in Hungary. J Clin Virol. 2010; 47: 379-381.

[9] Reuter G, Új M, Pankovics P, et al. Clinical significance and the first identification of human parechoviruses in Hungary. [A humán parechovírusok klinikai jelentősége és első hazai azonosítása.] Orv Hetil. 2011; 152: 1007-1012. [Hungarian]

[10] Romero JR, Selvarangan R. The human Parechoviruses: an overview. Adv Pediatr. 2011; 58: 65-85.

[11] Palmenberg A, Neubauer D, Skern T. Chapter 1. Genome organization and encoded proteins. In: Ehrenfeld E, Domingo E, Roos RP. (eds.) The Picornaviruses. ASM Press, Washington, DC, 2010; pp. 3-17.

[12] Kalynych S, Pálková L, Plevka P. The structure of human parechovirus 1 reveals an association of the RNA genome with the capsid. J Virol. 2016; 90: 1377-1386.

[13] Harvala H, Robertson I, McWilliam Leitch EC, et al. Epidemiology and clinical associations of human parechovirus respiratory infections. J Clin Microbiol. 2008; 46: 3446-3453.

[14] Aizawa Y, Yamanaka T, Watanabe K, et al. Asymptomatic children might transmit human parechovirus type 3 to neonates and young infants. J Clin Virol. 2015; 70: 105-108.

[15] Yun Z, Ekwall J, Jerkérus SF, et al. A case of intrafamilial human parechovirus type 3 infections resulting in sepsis-like illness in a neonate but hand, foot and mouth disease in an elder sibling. J Clin Virol. 2015; 70(Suppl 1): S62-S63.
[16] Nielsen NM, Midgley SE, Nielsen ACY, et al. Severe human parechovirus infections in infants and the role of older siblings. Am J Epidemiol. 2016; 183: 664-670.

[17] Wildenbeest JG, Benschop KS, Minnaar RP, et al. Clinical relevance of positive human parechovirus type 1 and 3 PCR in stool samples. Clin Microbiol Infect. 2014; 20: O640-O647.

[18] Ferreras Antolín L, Kadambari S, Braccio S, et al. Increased detection of human parechovirus infection in infants in England during 2016: epidemiology and clinical characteristics. Arch Dis Child. 2018; 103: 1061-1066.

[19] Kumar S, Stecher G, Tamura K. MEGA7: Molecular Evolutionary Genetics Analysis version 7.0 for bigger datasets. Mol Biol Evol. 2016; 33: 1870-1874.

[20] Vennema H, de Bruin E, Koopmans M. Rational optimization of generic primers used for Norwalk-like virus detection by reverse transcriptase polymerase chain reaction. J Clin Virol. 2002; 25: 233-235.

[21] Fischer TK, Midgley S, Dalgaard C, et al. Human parechovirus infection, Denmark. Emerg Infect Dis. 2014; 20: 83-87.

[22] Kolehmainen P, Oikarinen S, Koskiniemi M, et al. Human parechoviruses are frequently detected in stool of healthy Finnish children. J Clin Virol. 2012; 54: 156-161.

[23] Walters B, Peñaranda S, Nix WA, et al. Detection of human parechovirus (HPeV)-3 in spinal fluid specimens from pediatric patients in the Chicago area. J Clin Virol. 2011; 52: 187-191.

[24] Mizuta K, Kuroda M, Kurimura M, et al. Epidemic myalgia in adults associated with human parechovirus type 3 infection, Yamagata, Japan, 2008. Emerg Infect Dis. 2012; 18: 17871793.

[25] Aizawa Y, Watanabe K, Oishi T, et al. Role of maternal antibodies in infants with severe diseases related to human parechovirus type 3. Emerg Infect Dis. 2015; 21: 1966-1972.

[26] Wildenbeest JG, Wolthers KC, Straver B, et al. Successful IVIG treatment of human parechovirus-associated dilated cardiomyopathy in an infant. Pediatrics 2013; 132: e243-e247.

(Reuter Gábor dr., Pécs, Szigeti út 12., 7624 e-mail: reuter.gabor@gmail.com)

\title{
A rendezvények és kongresszusok híranyagának leadása
}

\author{
a lap megjelenése előtt legalább 40 nappal lehetséges, a 6 hetes nyomdai átfutás miatt. \\ Kérjük megrendelőink szíves megértését.
}

\author{
A híranyagokat a következő címre kérjük: \\ Orvosi Hetilap titkársága: edit.budai@akademiai.hu \\ Akadémiai Kiadó Zrt.
}

A cikk a Creative Commons Attribution 4.0 International License (https://creativecommons.org/licenses/by/4.0/) feltételei szerint publikált Open Access közlemény, melynek szellemében a cikk bármilyen médiumban szabadon felhasználható, megosztható és újraközölhető, feltéve, hogy az eredeti szerző és a közlés helye, illetve a CC License linkje és az esetlegesen végrehajtott módosítások feltüntetésre kerülnek. (SID_1) 